\title{
Uma Tradução
}

Operosa: O Verbo

"Rebentado" na

Escrita de José

\section{Maria Arguedas}

Afonso Rocha Lacerda

Recebido em: 30 de setembro de 2016

Aceito em: 07 de novembro de 2016
Mestre em Letras (2015) pela Faculdade de Filosofia, Letras e Ciências Humanas da Universidade de São Paulo (USP), é graduado pela mesma faculdade em Filosofia (2002). Há treze anos atua no ensino municipal da cidade de São Paulo. Interessa-se pela literatura moderna hispano-americana, exercitando uma investigação na qual dialogam a Estética, a Filosofia da História e a Teoria Literária. Contato: lacerda.afonso@gmail. com 
Palavras-chave: mímesis; tradução; metáfora; fronteira; figura.

Keywords: mimesis; translation; metaphor; borderline; figure.
Partindo do diálogo entre dois personagens de um capítulo dos Zorros de Arguedas, intentamos investigar as formas transversas, oblíquas, da significação na linguagem do romance. Associa-se a este propósito, uma perspectiva que leva em conta a função da metáfora na narrativa. Amparamo-nos amplamente na reflexão desenvolvida por Paul Ricoeur sobre a metáfora, além de levar em conta a compreensão benjaminiana da tradução, que envolveria uma ideia de "plenitude das línguas". Para a referida análise, assume relevância a ideia de uma tradução implicada no manifesto desejo do autor de restabelecer o vínculo perdido com as coisas. Esta aspiração de uma forma de expressar-se que dispensaria mediações, ao que nos parece, funciona como fio condutor na construção do capítulo estudado. Buscamos mostrar que - fracasso ao qual estaria condenado de antemão um ideal como este é contrabalançado pelo esforço laborioso da criação de um solo por intermédio da linguagem.

The present paper examines the oblique and deviating forms for meaning in the novel Zorros by José María Arguedas. In order to do so, we analyze the dialogue between two characters in one of the chapters. Our perspective considers the function metaphor can assume in a narrative text. Paul Ricoeur's study on metaphor supports this reflection, as well as Walter Benjamin's understanding of the translation as "languages plenitude". It is also relevant the idea of translation as a way of restoring a bond. From our perspective, this wish for an expression that could dispense with mediations organizes the referred chapter. We aim to demonstrate that the effort for creating a ground through language counterbalances the obvious failure of this enterprise. 
Uma Tradução Operosa: O Verbo “Rebentado” na Escrita de José Maria Arguedas

"Que los colores no sean sólo una maraña, la grotesca huella del agitarse

del ser impotente; eso es lo esencial."

(José Maria Arguedas)

Em ensaio publicado em 1950, La novela y el problema de la expresión literaria en el Perú (1993), José Maria Arguedas manifestara a necessidade de uma língua própria, capaz de dar conta de singularidades impossíveis de serem transpostas do falar quéchua para a escrita em castelhano. Ele narra os descaminhos de sua luta pelo estilo, evidenciando o inexorável trânsito entre línguas distintas com que tem de se haver o escritor preocupado em retratar o universo andino. "Realizarse, traducirse, convertir en torrente diáfano y legítimo el idioma que parece ajeno, comunicar a la lengua casi estranjera la materia de nuestro espíritu. Esa es la dura, la difícil cuestión" (José Maria Arguedas, 1993, p. 213). Atravessando toda a criação de Arguedas esta questáo adquire particular relevância em sua última obra, El Zorro de Arriba y el Zorro de Abajo, publicada postumamente em 1971. A elaboraçáo traumática desta narrativa, na qual o escritor buscava fazer justiça à realidade movente de Chimbote, pode ser pensada como o eixo da reflexáo aqui ensaiada, assim como a relação que será estabelecida entre sua poética e uma teoria da metáfora. Centraremos nossa análise no capítulo quarto do romance, todo ele desenvolvido em torno de duas longas conversas entretidas pelos personagens Esteban de La Cruz e seu compadre, o negro Moncada. Tais conversas teriam acontecido em diferentes ocasióes na casa deste último e Esteban as rememora, nas imediaçóes do Mercado La Linea, depois de 
despachar sua mulher Jesusa para que volte sem ele a casa, pois o cansaço impede-o que a acompanhe.

Nossa leitura do texto de Arguedas ampara-se em uma concepçáo da metáfora que se aproxima da ideia de disposiçâao figural. Com isso ela se vincula à reflexáo sobre a mímesis desenvolvida por Luis Costa Lima (1995). Tendo por base a leitura que faz do ensaio Figura, de Erich Auerbach, o crítico rechaça a largamente difundida concepção clássica da mímesis, pela qual ela é restringida à imitatio. Seguindo o mesmo raciocínio a metáfora tenderia a ser pensada como mero ornamento. Ele aponta para a importante distinção entre a disposição figural e a alegórica. De acordo com Costa Lima a mímesis se caracterizaria pela plasticidade presente na raiz do vocábulo figura. Na alegoria tal plasticidade é corrompida, havendo um processo de hierarquização que subordina a ocorrência sensível-histórica a uma ideia de correspondência abstrata e intelectual. "O termo propriamente dito da figura passaria a se confundir com o mero suporte sensível de uma promessa (Costa Lima, 1995, 226)." Veremos que este resgate da plasticidade da mímesis tem conotaçóes muito semelhantes à perspectiva elaborada por Paul Ricoeur em A Metáfora Viva (2000). Sua ideia de referência duplicada, que mais adiante se delineará, permite estabelecer uma relação estreita entre metáfora e mímesis.

Neste sentido, embora a análise aqui realizada tome como elementos as metáforas e os oxímoros, caracterizados pelo amalgamar de ideias paradoxais em imagens unitárias - figuras presentes nas falas de Esteban e de Moncada -, ela consiste em uma reflexão sobre a mímesis em Arguedas. A aproximação das tensôes subjacentes à linguagem do romance exigirá que se 
Uma Traduçāo Operosa: O Verbo “Rebentado" na Escrita de José Maria Arguedas

leve em conta a tentativa que El Zorro representa de figurar a realidade de Chimbote. Na utilização das figuras reside, portanto, o esforço da narrativa por estruturar-se e dar conta de expressar um estado de coisas, sem que possa alicerçar-se em esquemas ou valores já dados. Além disso, a plasticidade requerida pela mímesis é sugerida por outro expediente. Conforme mencionamos, a narrativa do capítulo reencena diálogos já havidos entre os personagens, presentificados por meio do discurso direto. A reencenação das falas por Esteban, personagem que, tal como Arguedas, se instala no limiar entre o castelhano e o quéchua, se reveste de uma propriedade interessante ao permitir que a conversa havida se desdobre, desprendendo-se da sua virtual origem, sendo por sua vez reencenada a cada leitura que se faz do romance.

A cena que se descortina no início do capítulo é a do fim de mais uma jornada da dura faina de Jesusa e Esteban. A extenuação deste último é agravada por sequela herdada de uma existência sucedida em outros trabalhos, ocasional e infalivelmente lembrada pela falta de fôlego e pelos acessos de tosse que lhe acometem. Tendo ficado para trás, ele é obrigado a permanecer estirado longo tempo no chão, enquanto recupera suas energias, nesse ínterim passa a lembrar-se do que lhe perguntara seu amigo Moncada acerca das minas de Cocalón: “¿Cómo era Cocalón? - mi dijo -. ¿Cómo muere allí, dijo usté, la joventud del indiada (Arguedas, 1996, 137)?” Instado a falar desta estância, a densidade das recordaçóes de Esteban comprime-se no tempo de uma tarde ou pouco menos, potencializando a agonia de uma peregrinação há muito iniciada. Cocalón figura o peso do destino de Esteban, lá nas suas minas ele "deixou" seu pulmão, quer dizer, contraiu o carvão contra o qual luta esforçando-se por extrai-lo de dentro do peito, o que ocorre a cada acesso de tosse. 
Don Esteban se arrodilló, extendió el periódico sobre la basura en pudrición y las moscas azules que danzaban sobre ella; se arrodilló calmadamente, empezó a toser y arrojó un esputo casi completamente negro. En la superficie de la flema el polvo de carbón intensificaba a la luz su aciago color, parecía como aprisionado, se movía, pretendía desprenderse de la flema en que estaba fundido (Arguedas, 1996, 131-132).

A esperança na qual Esteban se agarra, de que consiga expelir as cinco onças de carvão e, com isto, redimir-se reveste este quadro de certa transcendência. Num gesto persignado e metódico ele se ajoelha sobre o monturo de lixo em decomposição estendendo sobre ele a folha de jornal, em fervor quase religioso. Se alguma esperança pode haver, todavia, ela necessita ser provada espelhando-se no diário, contra o fundo negro sobre branco dos jornais periódicos. Deve ser conseguida a custo de que não se desviem os olhos da matéria pútrida em cujo interior trabalham, invisível e silenciosamente, minúsculos e desprezíveis vermes. São imagens dotadas de forte carga imanente. A chance que Esteban pode entrever, de salvar-se, a única pela qual sabe ter de lutar, consiste em extrair a luz aprisionada na fleuma carbonífera arrancada neste escarro. ${ }^{1}$

1. O jogo entre transcendência-imanência, aqui, nos remete à incandescência ou luminosidade da anchova processada pelos gigantescos dentes metálicos da máquina no interior da fábrica Nautilus Fish, no terceiro capítulo do romance. Não se trataria da própria "incandescencia del sol" amassada pelos estrangeiros em Chimbote, mencionada por Moncada em seu diálogo com Esteban (Arguedas, 1996, 142)? Evocando tal imagem, William Rowe comenta. "'Sólo la vida produce um brillo como ése que está viendo mi ojo. Y en esta poca luz, el mar nos manda su resplandor que nosotros apagamos y convertimos en otra vida; pero la muerte es como ese gusano que está en el vacío de cemento' (Arguedas, 1996, 120).” “[...] El 'resplandor' que manda el mar, habla de 
Uma Traduçāo Operosa: O Verbo “Rebentado" na Escrita de José Maria Arguedas

Afonso Rocha Lacerda

Enfim, não pode haver esperança, é o que nos parecem indicar as figuras ambíguas por extremo que despontam na narrativa, sem este quadro que tenderíamos a interpretar como a negação de sua possibilidade. Portanto a salvação esperada por Esteban não atinge sua plenitude em um registro transcendente, depurado, mas nas imagens viscerais figuradas nas linhas do romance. $\mathrm{O}$ texto de El Zorro se desenvolve de modo a deixar evidente, mais que tudo, este processo de "fervura", ebulição de toda matéria: "Está de candela infierno extraviado las conciencias” (Arguedas, 1996, 154), conclui Esteban de La Cruz. Despontam na narrativa figuras a evocar a miscibilidade de matérias decompostas, lama, emanaçóes fumegantes, chaminés botando fumos de distintas cores, manchas de óleo que se espraiam, eclosão de vermes; parecem significar o mergulho na realidade concreta suplantando o dualismo implícito de uma concepção da vida desgarrada e distanciada da sensorialidade. Mesmo a suposta diferença entre transcendência e imanência parece ser suprimida dando lugar a outros sistemas de oposição, nos quais, arriscaríamos dizer, um certo "lastro ontológico" não seria infenso às metáforas e inovaçôes semânticas. ${ }^{2}$

Com o acima exposto, torna-se conveniente esboçar uma análise do anseio mais de uma vez expresso no romance de Arguedas, ora nos "diários"

uma concepción trascendente de la naturaleza; la 'otra vida' que produce el proceso industrial, es inmanente, no enajenable (Rowe, 2010, 78)."

2. Esta supressão é postulada por Bruno Latour ao tratar da etimologia ambígua de "fato" e "fetiche": "Mas cada uma das palavras insiste simetricamente sobre a nuance inversa da outra. A palavra "fato" parece remeter à realidade exterior, a palavra "fetiche" às crenças absurdas do sujeito. Todas as duas dissimulam, na profundeza de suas raízes latinas, o trabalho intenso de construção que permite a verdade dos fatos como a dos espíritos. [...] Ao juntar as duas fontes etimológicas, chamaremos fe(i)tiche a firme certeza que permite à prática passar à açáo, sem jamais acreditar na diferença entre construçáo e compilaçáo, imanência e transcendência" (Latour, 2002). 
que são intercalados a alguns dos capítulos, ora no diálogo das míticas raposas que o intitulam; trata-se do "decir limpio", do dizer ou falar limpamente. Divisamos um paralelo possível entre tal anseio e a poderosa tensão envolvida no esforço de Esteban por lembrar-se. A dedicada operosidade por meio da qual trata de extrair os resquícios escuros que lhe oprimem o peito também é uma forma de evidenciar este esforço relacionado à expressão. Analisemos a passagem na qual Esteban suspende sua intervençáo no diálogo, motivado pela busca de palavras mais adequadas, em castelhano, de modo a se fazer entender por Moncada. Tal suspensão envolve, efetivamente, um esforço tradutório. "Sí, pues aunque sano toavía, entonces, cansaba boscando palabra castellano para contar bien, claro, a me compadre (Arguedas, 1996, 137)." Quer tenhamos em mente a fala de Esteban, quer estejamos preocupados com o ofício do escritor na elaboração do romance, a busca pela transposiçấo ou tradução é sempre laboriosa. E se o decir limpio é erigido como ideal, talvez não seja mais do que para assegurar que não se derive para uma negaçáo de qualquer trânsito possível entre a matéria narrável e a enunciação do romance. As lembranças de Esteban podem seguir o seu curso quando a sua raiva (candela) é dosada, evitando-se o descaminho da raiva (infierno) que ele exorciza ordenando a si mesmo que tranquilize seu pensamento e que ande direito (Idem, 137).

A busca de Esteban pelas palavras adequadas em castelhano com as quais se faça entender equipara-se ao esforço que apressura o narrador dos diários, quando nos revela seu intento de "hablar con una mínima limpieza, como para que estas líneas puedan ser leídas" (Arguedas, 1996, 21). O mesmo pode ser afirmado do anelo manifestado no início do primeiro diário, onde 
Uma Traduçāo Operosa: O Verbo “Rebentado" na Escrita de José Maria Arguedas

o narrador fala-nos de sua angustiada busca por recuperar "el roto vínculo con todas las cosas" (idem, ibidem, p. 7). Não seria infundado pensar, a partir do que nestes trechos se enuncia, em uma concepção muito característica da linguagem, identificada ao ideal da ausência de mediaçóes entre o signo e aquilo que ele designa - uma concepção com ressonâncias míticas. Está além dos limites deste trabalho desenvolver as implicaçóes de uma concepção como esta, porém podemos dizer que as conclusóes que vislumbramos penderiam mais para os signos precários de uma exegese alegórica, tal como a que é postulada por William Rowe (2010).

Com o que acabamos de dizer, impóe-se um esclarecimento com respeito a duas importantes críticas da obra arguediana. Isto se mostrará pertinente para uma melhor compreensão da relação que enxergamos entre o caráter denotativo da metáfora e a mímesis, contrapondo-as às noçôes de mero ornamento ou de imitação servil e mecânica da realidade. Primeiramente, o recurso ao "alegórico" por parte de Rowe não contradiz aquela distinção já mencionada entre a disposiçáo figural e a alegórica. Compreendemos que na sua crítica o que ele chama de exegese alegórica está em consonância com a plasticidade figural. Por sua vez, o conceito de figural - e consequentemente a mímesis - que aqui se pleiteia pouco tem a ver com as "leituras figurais" que se costumou fazer das obras de Arguedas, cujos equívocos são adequadamente criticados por José Alberto Portugal (2011). Em uma nota Portugal explicita que a noção de figura da qual se serve (também ela amparada no já citado ensaio de Auerbach) funciona para caracterizar a relação da ficção com a história de um mundo. Ele esclarece o significado de submeter-se a interpretação do romance a uma "leitura figural" sem deixar espaço para dúvidas. 
No solo se trata de conectar la novela con la dinámica social de su tempo, sino que se trata de indicar que en la novela hay un vislumbre de lo que aún no es, algo así como la afirmación de um valor profético en su obra: la construcción de una figura. La representación artística de ciertos “eventos" de la dinámica social andina del futuro (Portugal, 2011, 93.)

O veredito de Portugal acerca desta tendência é taxativo, corre-se o risco de enveredar por uma exegese que realiza o sentido de modo uniforme, por uma "manera correcta de leer". Na mesma linha da subordinação do sensível ao espiritual, que mencionamos antes, a ficção é capturada por um discurso historiográfico revestido de crítica. "Ahora bien, es un modo de escritura el que hace posible esta lectura o este tipo de lectura se impone sobre los escritos, a los que reconfigura (Idem, 93)?” Em suma, desfeito este embaraço vinculado às terminologias empregadas pelos dois críticos, parece-nos que ambos se contrapóem ao mesmo risco de uma camisa-de-força que silencie e deturpe o texto arguediano.

Em que sentido a consideração do caráter denotativo da metáfora, como uma forma de atingir por via oblíqua os elementos sensíveis que escapam a uma designação precisa ou a qualquer linguagem prévia, vem a estar em consonância com a advertência feita acima? Uma resposta se afigura através da consideração dos oxímoros que o texto do capítulo estudado nos confronta, tais como as expressóes "teniebla-lumbre" ou "luz renegrida". O amálgama de conceitos contraditórios geraria um efeito de desvio ou suspensão da referência usual, literal, o que se realizaria em proveito de um sentido que está a acontecer. Esta é justamente a aplicação da metáfora concebida por Paul Ricoeur (2000). 
Uma Traduçāo Operosa: O Verbo "Rebentado" na Escrita de José Maria Arguedas

Em sua obra A Metáfora Viva, Ricoeur explicita os mecanismos daquilo que ele denomina uma "impertinência semântica". O autor chama nossa atenção para uma tese fundamental de sua teoria da denotação generalizada: "a suspensão da referência, no sentido definido pelas normas do discurso descritivo, é a condição negativa para que seja liberado um modo mais fundamental de referência, que é tarefa da interpretação explicitar (RICOEUR, 2000, pp. 349-350; destaques nossos).” Um pouco mais adiante delineia com mais precisão o modo como a metáfora "torce" a linguagem:

A autodestruição do sentido, sob a influência da impertinência semântica, é apenas o inverso de uma inovaçấo de sentido do enunciado inteiro, inovação obtida pela "torção" do sentido literal das palavras. Essa inovação de sentido constitui a metáfora viva (Idem, ibidem, 351; destaques nossos).

No derradeiro ensaio do seu livro, Ricoeur aborda o vacilante sentido das palavras realidade e verdade, problematizando-as. Admitindo o risco de um "efeito de abismo", recorre conscientemente ao que chama de "metáforas da metáfora". Um exemplo envolve a ideia da "visão estereoscópica" que a metáfora proporcionaria, lá onde uma consideração do sentido usual seria insuficiente. A ideia de referência oblíqua, que se depreende dos trechos citados, flerta também com este abismo que o entramado textual do quarto capítulo de El Zorro não deixa de sugerir.

Aventamos a hipótese de um papel destacado, na narrativa arguediana, reservado à indução ou impertinência semântica. O desvio do sentido, apenas potencializado pela utilização daquelas imagens, os oxímoros, é operado 
de modo mais abrangente na narrativa de El Zorro. O "acesso à referência num modo virtual” (Ricoeur) não é necessariamente garantido com a suspensão da "referência real", isto equivale a dizer que algumas imagens suscitadas na narrativa não chegam a coalescer, permanecendo como uma tensão difusa da linguagem. A explicitação disto poderia ser feita desde muitos caminhos, porém elegemos uma passagem específica capaz de dar conta do que estamos propondo.

Me compadre es complacencia. Es testigo de me vida, yo tamién de so vida. Nada más, pues. Para todos, loco, loco que manso predica; testigo de me vida, para mí. Yo bravo "homilde”, él, soberbio. Así la Santa Biblia; desigual, como el mina de carbón y el luz de "los cielos" qu'intraba por las ventanas al socavón más profundiento, pues; donde todos los obreros el pulmón hemos dejado (Arguedas, 1996, 136).

Entre os recursos que transparecem neste trecho como produto da elaboração linguística de falantes de quéchua cuja experiência profunda tem que expressar-se, forçosamente, em castelhano, como ocorre com Esteban, destaca-se a utilização de substantivos na forma adjetivada, "me compadre es complacencia". Existe, porém, outra característica que vai ganhando consistência por meio da mescla, muito marcada na narrativa arguediana de $E l$ Zorro, entre o nível mais condensado da materialidade e aquilo que haveria de mais etéreo, diáfano. Acerca de uma contraposição como esta, táo entranhadamente trabalhada na tessitura do diálogo dos dois personagens, a passagem erige um quadro que náo poderia ser mais claro. A luz celestial e o 
Uma Traduçāo Operosa: O Verbo “Rebentado" na Escrita de José Maria Arguedas

recôndito mais profundo da terra são indissociáveis na visão que se apresenta. Ajudam a compor extratos coadjuvantes na fala e no temperamento das personagens. Assim é também a própria escritura da Bíblia, segundo Esteban, "desigual". Estes dois âmbitos são roçados pela linguagem, ou melhor, somente por intermédio dela a tênue luminosidade e a obscuridade mais densa chegam a se tornar palpáveis.

Seria, talvez, mais adequado dizer que a linguagem mesma somente vem a lume desde que haja participação entre estas duas matérias tão desiguais? Seguindo por esta via, não será demais insistir naquele expressado anelo de que se transmita à palavra a matéria das coisas. Aspiração cujo teor nos remete ao fracasso de uma referência direta, e que também é divisada ao longo da narrativa propriamente romanesca de El Zorro. A noção de desvio é prolífica não só para que possamos compreender o jogo entre o sentido "próprio" e o figurado, mas tem implicaçóes para o que se opera na tradução, especialmente quando o lugar de chegada da língua é a instância instável interposta entre o quéchua e o castelhano. Uma sequência bastante sugestiva deste fenômeno da autoprodução da língua sugere a tensão existente entre o inefável e a busca determinada de enraizamento.

A narrativa dos diálogos entre Esteban e seu compadre Moncada é retomada, depois de ficarmos sabendo da investida do segundo e de sua prédica interrompida, no hall do Hotel Chimú, onde se reuniam autoridades e pessoas importantes da sociedade chimbotana.

'Dispués, otra noche, me compadre, mi'a hecho sentar en so catre. [...] 'Compadre - mi dijo, diciendo -. ¿Cómo has salido de mina Cocalón? 
¿Adónde has ido? ¿Cómo has entrado a Chimbote?’ En el ojo de me compadre, cuando no hay su locura, es tranquilo, querendoso. Me pierna no alcanzaba al suelo. ¡Caray, gracioso! Su catre de me compadre es altazo, sos patas con ruedecita (Arguedas, 1996, 146.).

Esteban é instado novamente a encontrar as palavras com que repostar as questôes que lhe são feitas. E não se trata, absolutamente, de questôes triviais. As exigências de Moncada são condignas de alguém que, como Esteban bem observara, "es testigo de me vida". A busca pelas palavras com as quais estas questóes tão cruciais sejam satisfeitas, no entanto, repóe um problema para um habitante de fronteiras. Esteban constata que sua perna não alcançava o solo firme e, com isto, parece-nos sugerir nada menos do que uma isotopia semântica com o solo firme da linguagem que demanda para dar conta da incumbência que sobre ele recai uma vez mais. Contudo ele narra o seu périplo, malgrado as dificuldades que encontra. Pouco adiante, porém, somos novamente confrontados com a constataçáo inexorável desse difícil caminhar.

- ¿Liriobamba, compadre? -preguntó Moncada, apenas entró de vuelta a su casa-. Eso quiere decir pampa de lirios.

- Cierto - dijo don Esteban. Mecía sus pies en el aire, porque no alcanzaban a llegar al suelo. El catre del loco era muy alto -. Compadre, estoy pensamiento... Quizás el evangélico de Chimbote es..., ¿cómo ostí dice? ¿Desabridoso?

- Desabrido. 
Uma Traduçāo Operosa: O Verbo “Rebentado" na Escrita de José Maria Arguedas

Afonso Rocha Lacerda

- Eso mismo, en quichua, más seguro dice qaima. Pero, diga ostí. Ese desabridoso, qaima, hace conocer a profeta Esaías. Grandazo es; parece le habla el Huascarán, cerro nieve macizo, con negros piedras en sus partes feos. Oiga, compadre... 'Tos ojos alza en derredor... andarán en luz... mira... éstos se han juntado... tus hijos vendrán de lejos (como ostí, compadre, como yocito)... sobre el lodo serán criados... entonces verás, resplandor... se maravillará to corazón, ensanchará, tempestad...'

Moncada vio que el cuerpecito de don Esteban se afianzaba en el aire, tomaba peso, mientras recitaba, porque sus pies no llegaban al suelo (Arguedas, 1996, 153-154).

As hesitações ou o cansaço são obstáculos que Esteban precisa superar para prosseguir contando os fatos que lhe sucederam. Em outros níveis, o processo narrativo adquire outras conotaçóes, como a que o relaciona ao ato de expelir o carvão (veneno) aprisionado no peito, por exemplo. ${ }^{3}$ A relação entre o falar/narrar e o andar, ao mesmo tempo, vem a ganhar maior consistência se lembrarmos de uma importante observação de Monte Alto (2011), na qual ele demonstra a filiação do último romance arguediano à linhagem inaugurada por Guamán Poma de Ayala com sua Nueva corónica y buen gobierno. ${ }^{4}$

3. O ato de expelir o carvão que traz no peito também possibilita estabelecer uma identificação entre Esteban e Arguedas: "La identificación entre Esteban de la Cruz y Arguedas (lo que no implica en absoluto una homologación entre autor y personaje) se completa desplegando la compleja interrelación entre la imagen de Esteban escupiendo carbón y la de Arguedas escribiendo" (Cortés, 2011, 151).

4. De acordo com o autor, "a figura criada por Guamán Poma, de um autor que caminha e se preocupa com a migração dos índios em direção às cidades, deixando vazias as terras e as minas, remete a Arguedas sobre suas andanças pela serra, sobre a mobilidade de sua escrita, que viajou 
A isotopia mencionada reafirma-se em uma sucessão de figuras que o trecho citado já anuncia, quando é mencionado o lodo nos trechos adaptados de Isaías: “Tus hijos [...] sobre el lodo serán criados"; também a constatação de que a récita dos trechos proféticos dava ao corpo franzino de Esteban peso e consistência. $\mathrm{O}$ tom da palavra profética de Isaías, capaz de acender em brasa e converter em coisa distinta o "carbón maldecido" que sai da boca de Esteban, aparenta-se, do mesmo modo, ao caminhar firme estimulado pelo amigo Moncada: "Pisar firme la tierra, compadre, sin miedo, sin miedo. Más firmeza toavía que usté y que yo, qui'andamos foribundos ningunos sabemos bien pa'dónde" (Arguedas, 1996, 154). Ousamos, neste passo, identificar o "tomar peso" do corpo, assim como o andar furibundo e com firmeza a um detalhe adicional presente na passagem, trata-se da aparente hesitação de Esteban entre a correção "oficial" (castelhana) do termo que precisa para prosseguir e o termo quéchua que para ele parece mais preciso, porém não funcionaria para o seu interlocutor. Entre "desabrido" e "qaima", ele resolutamente mantém o neologismo da soluçáo original: "desabridoso". ${ }^{5}$

Por sinal, "desabridoso" é o evangélico, o qual "no tiene sal [...] menos pimienta", embora seja por seu intermédio que Esteban tenha conhecido o profeta Isaías: "Grandazo es; parece le habla el Huascarán...”.

da perspectiva de um povoado em direçâo à cidade grande, e finalmente, sobre a nova sintaxe que se está formando nas periferias dos grandes conglomerados urbanos, resultado da migração contemporânea que experimentou o país" (Monte Alto, 2011, 99).

5. Embora não possamos asseverar de modo absoluto, parece-nos possível que o termo "desabridoso" seja resultante de uma analogia por antonomásia com "sabroso". 
Uma Tradução Operosa: O Verbo “Rebentado” na Escrita de José Maria Arguedas

Afonso Rocha Lacerda

- El evangélico no chupa, no miente, es limpio - dijo -. Pero... su aliento, quiero decir, su vida, tomado en su completo, es desabrido. No tiene sal, compadre, menos pimienta. Ni animal ni persona con su rińón de gente, con su lengua completa de gente, con su barriga y entrepierna completos; el evangélico está fugado. [...] Hasta el perro, hasta el carnero, hace sentir su vida cuando ladra el uno; cuando brama el otro, al sentir el cuchillo en el pescuezo.

- ¿Y el chancho, compadrito?

- El chancho es majestad en su... claro, compadre! en su habla. He sido chanchero del chancho de corral u de chacra, no, pues, del encajonado en granja. Mucho he aprendido de los chanchos. El sentimento, el alegría que es comer sabendo en el hocico, así de largo, en la lengua, el calorcito, el olorcito del alimento mesclado de harina de pescado con otras cositas; el sonar "profondo del garganta" como usté dice, templado, con su melodía como seda o como tripa, en que lumbres y raíces del mundo, del mismo culo de la tierra se manifiestan; ese gruńido, compadre. Ahí, en el gruñido destintos del chancho, sientes tú, compadre, el agua caliente y el agua frío, el barro, el aire limpio; el "pestelencia” y como usté dice el deshogo "buenazo" del defecar, del eructo ventocidad. ¿Y cuando sueltan a los chanchos para bañarse, compadre? Latiguean con su rabo chico el aire; su cuerpo gordo no salta mucho, pero nengún animal, ni gente, así goza de su movimento del cuerpo...(Arguedas, 1996, 150-151; destaques nosssos)

Esteban não pode deixar de se surpreender com o fato de que justamente através do evangélico "desabridoso" tenha vindo a conhecer o profeta 
Isaías, por ele identificado ao exato oposto deste conceito. ${ }^{6}$ Isaías encarna o tremendo maravilhoso, refletido na grandiosidade do monte Huascarán, remetendo também a alguns dos símbolos mágico-poéticos mencionados por Martin Lienhard (1990), especialmente a cascata de San Miguel de Obrajillo que aparece no primeiro diário e, consequentemente, também a "el chancho....majestad...en su habla": "La alta, la altíssima cascada que baja desde la inalcanzable cumbre de rocas, cantaba en el gemido de ese nionena, en sus cerdas duras que se convirtieron en suaves" (Arguedas, 1996, 8-9). É digna de nota a ênfase na sensorialidade, sem a qual o alento da vida em suas entranhas nâo pode ser alcançado. A experiência terrífica compartilha do mesmo fundamento que a experiência prazerosa.

Se a fala de Esteban pode tomar corpo, acesa pelo ímpeto de salvar-se ainda que na hora fatal, e se ela pode se alimentar do tom "teniebla-lumbre" da fala de Isaías, é porque há nela profundidade que se alimenta da raiva (candela) de que são portadores apenas os "endemoniados" como o próprio Esteban e também Moncada.

El Hermano dice soy algo demonio y que salvaré al hora del morir... Salvaré escopiendo hasta so final el carbón que hay taconeado en me pulmón. Entonces, papacito Esaías, ya me boca no hablará sapo, culebra; no patiaré sin efecto, como ahorita que no hay fuerza, a me mojir; endenoche no le haré suciedad hasta cayer como alcatraz moribondo al basuras. Caracho! Lindo

6. As composiçôes de Isaías "têm força concisa, majestade e harmonia que jamais serão igualadas. (...) Sua idéia de Deus tem algo de triunfal e também de pavoroso. (...) Isaías é o maior dos profetas messiânicos (Bíblia de Jerusalém, 2002, 1238).” 
Uma Traduçāo Operosa: O Verbo “Rebentado" na Escrita de José Maria Arguedas

se habla, en selencio, con el pensamiento, como el Dios. Igual. No cansa el pecho; tranqueliza más bien (Arguedas, 1996,. 136-137).

As negaçóes sucessivas conformam-se de modo a estruturar uma experiência da qual não se pode postular senão uma aproximação negativa. Uma experiência como esta que, para Esteban, consiste em falar com o pensamento, sem cansar o peito e que, conforme ele nos diz na passagem, se assemelha a Deus. Este falar divino endereça-nos para uma consideração do sublime. Esteban somente pode aproximar-se desse falar tão direto, que prescinde daquele esforço da linguagem e do peso em seu peito, de modo negativo. A correspondência perfeita suposta nesta concepção da linguagem subsiste como virtualidade, horizonte inalcançável no qual o vínculo perdido com a natureza se restabeleceria.

A transparência possibilitada pela ausência de mediação que se deixa entrever na linguagem aspirada por Arguedas - uma linguagem adâmica que também parece ser o telos almejado pelo personagem Esteban - endereça-nos a um ideal de tradução específico. Referimo-nos à ideia de "pura linguagem" como aquela que emerge da concepção benjaminiana da tradução.

$\mathrm{Na}$ tradução, o original cresce e se alça a uma atmosfera por assim dizer mais elevada e mais pura da língua, onde, é claro, não poderá viver por muito tempo, da mesma forma como o original sequer alcança tal atmosfera com todas as partes de sua composição, mas à qual de modo prodigiosamente insistente, ele ao menos alude, indicando o âmbito predestinado e interdito da reconciliaçáo e plenitude das línguas. Jamais ele o alcança de uma 
vez por todas: mas nele está o que numa tradução ultrapassa a comunicação (Benjamin, 2010, 215).

No que a atmosfera mais elevada e mais pura da língua, tal como a concebe Walter Benjamin, reveste-se, conceitualmente falando, de traços de uma reflexão teológica sobre a linguagem. A palavra é expressão carregada de sentido; a linguagem adâmica pressupóe o entendimento de que a palavra vem a ser dotada de carga simbólica, permanecendo qualitativamente relacionada àquilo que significa (cf. Rouanet, 1981). Isto evoca o anseio por reatar o vínculo entre a palavra e a matéria que ela descreve manifestado por Arguedas. A linguagem à qual se refere Esteban também participa desta aspiração capaz de suplantar o cansaço e os impasses ocasionados pelo esforço tradutório. Se a interdição parece levar vantagem conforme a narrativa de El Zorro nos leva a crer - e a tradutibilidade transparece, portanto, como esforço vão -, ela não deixa de testemunhar a autoprodução de um solo próprio que a linguagem laboriosamente constrói. Este ideal é pensado, ou projetado, como um telos, uma utopia messiânica, a qual ressurge de maneira recorrente nas referências proféticas que despontam em diversos momentos do texto, como na seguinte fala de Moncada:

“- Estamos demoniados, compadre. ¿Quién no? Si no le meto ripio y tierra a este suelo de mi cuarto cada dos meses, el catre se hunde en el fango, ¿no? Y de aqui también, la Corporación nos va botar, compadre (Arguedas, 1996, 154)." Do mesmo modo em uma fala indireta, o relato feito por Jesusa ao pastor evangélico (el Hermano), onde com veemência predestinada Esteban nos pinta um quadro que faz ver como daquelas bases mais inconsistentes e impuras um mundo novo será construído. 
Uma Tradução Operosa: O Verbo “Rebentado” na Escrita de José Maria Arguedas

Afonso Rocha Lacerda

'Esaías - ha dicho, Hermano, como hereje, el Estebán-. Sapo Esaías; chicharras, gente chico, nosotros, zancuditos, cojudos, borrachos que'hemos nacido a montonazos. Del barro negrociento habla sapo contra del oscuro, bravo. No le hace contagio pudrición homildad, barro fango, carajo. Pa'él no hay oscuro: al revés. Este homanidad va desparecer, otro va nacer del garganta del Esaías. Vamos empujar cerros; roquedales pa'trayer agua al entero médano; vamos hacer jardín cielo; del monte van despertar animales qui'ahora tienen susto del Cristiano; más que caterpilar van empujar...todo, carajo, todo; van anchar quebrada Cocalón, mariposa amarillo va respirar lindo. Este totoral namás va quedar para recuerdo del tempo del sangre del Jesusa, del predicación de mi compadrito.' (Arguedas, 1996, 157)

A veemência e a força que brotam desta palavra profética mantêm uma correlação estreita com a capacidade autoprodutiva da linguagem, à qual aludimos pouco acima.

Através do profetismo e da loucura, com efeito, o verbo aponta uma perspectiva de convergência capaz de desafiar a própria constatação do interdito que paira sobre a tradução. A reinvenção constante da expressão é movida pela necessidade de transpor mais coisas do que aquilo que o texto original comunica. $\mathrm{O}$ que na linguagem do romance equivale a ir além da cáscara (concha). $\mathrm{O}$ aspecto meramente comunicativo do que se intenta traduzir resta em uma dimensão pura da língua, na qual não poderá viver por muito tempo, conforme afirma Benjamin. Conformar-se às particularidades do que se intenta traduzir ou transpor depende da aceitação de um aparente paradoxo, que Horácio Legrás nos apresenta nos seguintes termos: "uma 
tradução bem sucedida é sempre uma tradução fracassada".? Ainda que fatalmente inatingível de forma definitiva, náo deixa de haver o elo entre signo e realidade. Ao tratar disso, Walter Benjamin fala em um "modo de semelhança” o qual, segundo ele:

[N]ão é ilustrado apenas pelas relaçóes, nas línguas diversas, das palavras com o mesmo. Assim como não se pode restringir a indagação à palavra falada. Ao contrário, ela tem muito a ver com a palavra escrita. É pois digno de atenção que a palavra escrita - em alguns casos mais pregnante que a falada - ilumine, pela relaçáo de sua forma escrita com o significado, a natureza de sua semelhança imaterial (Apud Lima, 1995, 287). ${ }^{8}$

A noção de semelhança ou significado imaterial deixa-se entrever, voltando-se ao romance, em um pequeno trecho já destacado pouco acima, quando Esteban vislumbra uma fala desprovida das constritivas impurezas que lhe angustiam: "Lindo se habla, en selencio, con el pensamento, como el Dios. Igual” (Arguedas, 1996, 137). A veemência da fala proferida por Esteban, assim como por Moncada, conforme temos visto, provém de uma reverberaçáo do indizível, mantém a tensão entre a convergência para uma linguagem paradisíaca e uma intradutibilidade trágica. Esta reverberação do indizível é figurada pela perplexidade da linguagem ante o incomensurável que a silencia.

7. "[A] successful translation is always a failed one (Legrás, 2008, 9. Tradução nossa)."

8. O trecho citado pertence ao ensaio de Walter Benjamin "Sobre a faculdade mimética" e é traduzido do original por Costa Lima. O crítico aproxima a hipótese de Benjamin da noção de transcriação postulada por Haroldo de Campos (Lima, 1995, 288). 
Uma Tradução Operosa: O Verbo “Rebentado” na Escrita de José Maria Arguedas

Poderíamos nos reportar a inumeráveis exemplos no romance, que parecem capturar o entrechocar-se perplexo da linguagem com o ilimitado, porém vamos nos ater a um número suficiente deles, os quais já constam em trechos acima citados: “[El] socavón más profundiento” por cujas janelas entra a luz do sol; a associação do profeta Isaías às divindades tectônicas, fazendo nele falar o Huascarán, "cerro nieve macizo, con sus negros piedras en sus partes feos"; O porco majestade em sua fala, de cuja profundeza da garganta soam "lumbres y raíces del mundo"; a fala do sapo no barreal, "contra del oscuro, bravo"; “empurrar cerros, roquedales” e construir "jardín cielo". Uma esfera como esta é roçada na fala de Esteban quando, sentado sobre o catre alto do amigo e indagando sobre o sentido mais preciso de uma expressão, lhe diz: "Compadre, estoy pensamiento" e, pouco mais adiante, ao término da longa digressão sobre suas conversas, se levanta e póe-se a pensar andando em direção a casa equilibrada sobre o lodaçal.

Se echó a caminar línea arriba, por el caminito que había junto a los rieles, 'Voy acabar de pensar andando', dijo. 'El pensamento en deveras es cosa de Dios, no hace cansar cuerpo, más bien hace entrar fuerza. ¿Será porque pura rabia, pura venganza namás recuerdo así con fuerza? [...]' (Arguedas, 1996, 156; destaques nossos).

Em cada uma destas expressóes às quais um silêncio desbordado se opóe desponta uma palavra que não se acaba de inventar. 


\section{REFERÊNCIAS BIBLIOGRÁFICAS:}

Arguedas, José María. El Zorro de Arriba y el Zorro de Abajo. Ève-Marie Fell (cord.). Madrid; París; México; Buenos Aires; São Paulo; Rio de Janeiro; Lima: ALLCA XX, 1996.

. "La novela y el problema de la expresión literaria en el Perú". Em Abelardo Oquendo (org.). Un Mundo de Monstruos y de Fuego. Lima: Fondo de Cultura Económica, 1993.

Benjamin, Walter. A Tarefa do Tradutor. Em Werner Heidermann (org.). Clássicos da Teoria da Tradução (Volume I). Florianópolis: Universidade Federal de Santa Catarina, 2010.

Bíblia de Jerusalém. São Paulo: Paulus, 2002.

Cortés, Daniel. Metáfora y metonímia en el Zorro de Arriba y el Zorro de Abajo de José María Arguedas, p. 134. Rétor, 1 (2), pp. 131-157, 2011.

Latour, Bruno. Reflexão Sobre o Culto Moderno dos Deuses Fe(i)tiches. Bauru, SP: EDUSC, 2002.

Legrás, Horácio. Literature and Subjection. Pittsburgh: Universidad de Pittsburgh, 2008. Lienhard, Martin. Cultura Andina y Forma Novelesca: Zorros y Danzantes en la Última Novela de Arguedas. Lima: Editorial Horizonte, 1990.

Lima, Luis Costa. Vida e mimesis. Rio de Janeiro: Ed. 34, 1995.

Monte Alto, Rômulo. Descaminhos do Moderno em José María Arguedas. Belo Horizonte: Ed. UFMG, 2011.

Portugal, José Alberto. Las Novelas de José María Arguedas: Una Incursión en lo Inarticulado. Lima: Fondo Editorial de la PUCP, 2011.

Ricoeur, Paul. A Metáfora Viva. São Paulo: Ediçôes Loyola, 2000.

Rouanet, Sérgio Paulo. Édipo e o Anjo. Itinerários Freudianos em Walter Benjamin. Rio de Janeiro: Tempo Brasileiro, 1981. 
Uma Traduçāo Operosa: O Verbo “Rebentado” na Escrita de José Maria Arguedas Afonso Rocha Lacerda

Rowe, William. “'No hay mensajero de nada': la modernidad andina según los Zorros de Arguedas"; Em Revista de Crítica Literaria Latinoamericana Año XXXVI, No 72. Lima-Boston, $2^{\circ}$ semestre de 2010, pp. 61-96.

. "Deseo, escritura y fuerzas productivas". Em Ève-Marie Fell (cord.). El Zorro de Arriba y el Zorro de Abajo. Madrid; París; México; Buenos Aires; São Paulo; Rio de Janeiro; Lima: ALLCA XX, 1996. 
